\title{
Thiel-Behnke corneal dystrophy
}

INSERM

\section{Source}

INSERM. (1999). Orphanet: an online rare disease and orphan drug data base. ThieBehnke corneal dystrophy. ORPHA:98960

Thiel-Behnke corneal dystrophy (TBCD) is a rare form of superficial corneal dystrophy characterized by sub-epithelial honeycomb-shaped corneal opacities in the superficial cornea, and progressive visual impairment. 